\title{
The Role of Quality Management in Improving Competitiveness and Performance of Moroccan Organizations
}

\author{
Omar Taouab \\ Soumaya Outellou
}

Department of Economics and Management

ENCG, Ibn Tofail University, Kenitra, Morocco

Doi:10.19044/esj.2020.v16n28p263 URL:http://dx.doi.org/10.19044/esj.2020.v16n28p263

Submitted: 19 August 2020

Accepted: 13 October 2020

Published: 31 October 2020

Copyright 2020 Taouab.

Distributed under Creative Commons CC-BY 4.0

OPEN ACCESS

\begin{abstract}
This paper focuses on introducing the term "quality management" and to showcase its relationship with ISO 9000 certification, as well as its impact on competitiveness and performance of Moroccans organizations. A research method strategy was used, which began with some assumptions on the subject. This was followed by the collection of theoretical and empirical data which helped uncover new information and created a better understanding of the topic.
\end{abstract}

Keywords: Quality management, competitiveness, performance, organization.

\section{Introduction}

Nowadays, management in general is one of the priorities of organizations. It helps improve performance and market leadership, which in turn increases international competitiveness. Organizations management implies dealing with different dimensions especially productivity management, cost, and quality, which are one of the major factors of a firm survival.

Quality is defined by the American Society for Quality Control (ASQC) as a set of features and characteristics of a product or a service that bears the ability to satisfy given needs. However, quality can be defined in many ways, depending on the perspective or the subject. 
Quality management is closely related to the concept of quality, and it is the heart and soul of the organization. It is a necessary tool to keep a competitive advantage by treating the customer's needs as top priority.

In Morocco, the term "quality" appeared recently in the 1990s. It is largely due to the economy globalization and increase in competition.

Therefore, it is important to discuss this problem and divide the questions in main and subsidiary ones as follows:

\section{Main Question (The Problem)}

- How can quality management improve the competitiveness of Moroccan organizations?

\section{Secondary Questions}

- How can we define quality management and what are the major contributions of this term?

- What are its principals?

- What are interests and limits of ISO 9000 certification for organizations?

- What is the impact of quality management of Moroccan organizations?

Before introducing the methodology and going into the subject details, it is appropriate to define the main keywords related to the problem. Also, relying on the proposed title "The role of quality management to improve competitiveness and performance of Moroccan organizations", five words attract our attention: quality, management, competitiveness, performance, and organizations.

\section{Definition of terms}

Management (or managing): This is the administration of an organization, whether it is a business, a not-for-profit organization, or government body. Management includes the activities of setting the strategy of an organization and coordinating the efforts of its employees (or volunteers) to accomplish its objectives through the application of available resources such as financial, natural, technological, and human resources. The term "management" may also refer to those people who manage an organization - individually known as the manager (Wikipedia).

Competitiveness: This refers to the ability of a firm or a nation to offer products and services that meet the quality standards of the local and world markets at competitive prices and provide adequate returns on the resources employed or consumed in producing them.

A company's competitiveness depends of the type of enterprise with respect to a benchmark. For example, competitiveness can be measured in the traded sector including firm profitability, the firm's export quotient 
(exports or foreign sales divided by output), and regional or global market share. Furthermore, the evaluation of a company's competitiveness can be represented by qualitative indicators such as the customer's judgment.

It should also be noted that the competitiveness of countries is quantified by several indicators such as export share, penetration rate, etc.

Organizations: This involves a social unit of people which is structured and managed to meet a need or to pursue collective goals. All organizations have a management structure that determines the relationships between the different activities, the members, subdivided assigned roles, responsibilities, and the authority to carry out different tasks. Organizations are open systems. This means that they affect and are affected by their environment.

Performance: Boisvert defined this word as "an outstanding result, out of the ordinary, which is optimal, and it is based on expectations that can be expressed in terms of objectives. However, the expectations are not formally expressed in terms of form of objectives"

Quality: The quality of a product or service lies in its ability to meet and fulfill the customer's needs (Margerand \& Gillet-goinard, 2007).

This is the simplest and most profound definition of the notion of quality. In other words, it can be said that a product or service has quality if the customer is satisfied after use. However, poor quality will create a sense of dissatisfaction.

Over the recent fifty years, the concept of quality has evolved a lot. This is because after the war, there was a tendency to associate the notion of quality with the conformity of product. Today, we can identify two notions. First, a final compliant product does not necessarily meet customer's needs (expected quality). Second, if the design of a product is done well (achieved quality), it may be compliant but not satisfactory.

This definition can be schematized as follows:

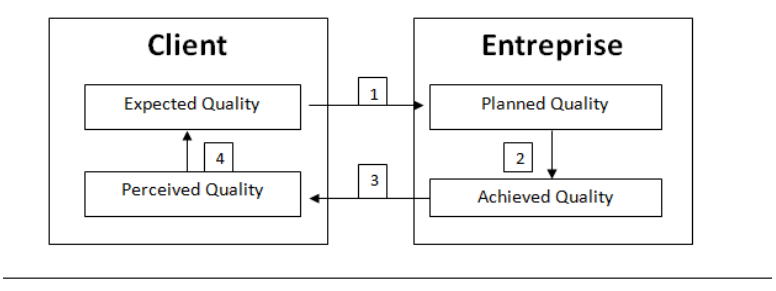

With:

Figure 1. Definition of quality (from client to enterprise)

1. Commercial study

2. Sequencing \& planification 


\section{Achievement}

4. Survey \& investigation

In literature, there are five approaches that express different point of view and perspectives about the quality of a product or services and they are complementary (Garvin, 1984).

Transcendent Approach: According to this approach, the quality is synonymous with excellence and perfection. It cannot be understood without experience. It is the approach of philosophers especially.

Product Approach: The quality is done through product specifications, for example, sustainability and reliability of product. If this approach is used, the quality can be evaluated objectively, and it is adopted by economists.

User Approach: As per user approach, the quality basically reflects the notion of satisfaction. It is a subjective and relative concept. This means that the definition of quality changes in terms of the function of customers or under the type of things that they search for to accommodate their needs and expectations.

Edwards Deming, author and consultant on quality, stated that the customer is the most important part of the production line. Thus, quality should be aimed at the present and future needs of the customer.

Therefore, the enterprise should design products and services with intentional differences in quality to meet different wants and needs of individual consumers (Rusell \& Taylor, 1997).

Among the dimensions of quality, primarily for manufactured products, a customer looks for the following in a product:

- Performance: This is the basic operating characteristics of a product, for example, how well a car can handle?

- Features: This is the extra items added to the basic features such as a stereo CD.

- Reliability: This is the probability that a product will operate properly within an expected time frame.

- Conformance: This is the degree to which a product meets reestablished standards.

- Durability: This determines how long the product lasts, i.e., its life span before replacement.

- Serviceability: This refers to the ease of getting repairs and the speed of repairs.

- Aesthetics: This refers to how a product looks, feels, sounds, smells or tastes. 
- Safety: This refers to the assurance that the customer will not suffer injury or harm from a product.

- Other perceptions: This includes subjective perceptions (Rusell \& Taylor, 1997).

Product Approach: In this approach, quality means the compliance of production to the characteristics of product or service. This approach particularly emphasizes the use of statistical techniques to control quality.

Value Approach: This approach sits on economical notion such as cost and price. Quality here is presented through the quotient, namely performance/price or compliance/cost.

\section{Assumptions}

The word "quality" and "management" when combined is termed as "quality management" (ISO 9000 Certification). Therefore, how can quality management be defined? And how can it affect the competitiveness and performance of enterprises and organizations?

On this basis, the following assumptions are raised:

1. Quality management can positively impact the enterprise by raising its competitiveness.

2. Quality management can push up the performance of an organization.

To confirm or affirm these assumptions, theoretical and empirical study is used.

\section{Definition and major contributions of Quality management}

Quality management is the central point of the subject and is defined as "coordinated activities to control an organization's quality".

This approach to the management of quality throughout the entire organization has evolved into what is referred to as Total Quality Management (TQM) (Rusell \& Taylor, 1997).

\section{Deming Contribution}

Among the founders of this term "quality management", Edwards Deming was one of them. He advocates continuous improvement of the production process to achieve conformance to specifications and reduce variability. He also credited the development of Deming wheel or Plan-DoCheck-Act (PDCA), which is a four-stage process for continuous quality improvement. 


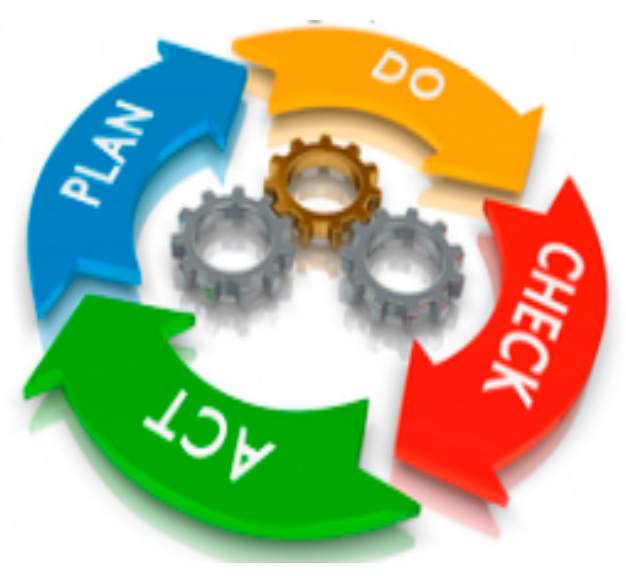

Figure 2. Deming cycle

\section{Stages of the Deming Wheel Process}

- Plan: In this first stage, customer expectations are determined.

- Do: This step engages the implementation of the action plan.

- Check: Deming changed the nomination of this stage in 1990 to study and show that exhaustive analysis of the plan should be made to see if the goals established in stage (1) are accomplished, and to check if there are some problems that occurred.

- Act: In this final phase, actions should be taken to standardize or improve the process and draw conclusions.

According to Deming, the success of quality approach largely depends on the role which the company's direction fulfills. This is because the company is responsible for the establishment of a quality strategy in the whole departments of enterprise. The author proposes 14 items of cluster ideas which could pilot managers to realize an excellent quality:

- Create constancy of purpose for improving products and services.

- Adopt the new philosophy.

- Cease dependence on inspection to achieve quality.

- End the practice of awarding business on price alone; instead, minimize total cost by working with a single supplier.

- Improve constantly and forever every process for planning, production, and service.

- Institute training on the job.

- Adopt and institute leadership.

- Drive out fear.

- Break down barriers between staff areas.

- Eliminate slogans, exhortations, and targets for the workforce. 
- Eliminate numerical quotas for the workforce and numerical goals for management.

- Remove barriers that rob people of pride of workmanship and eliminate the annual rating or merit system.

- Institute a vigorous program of education and self-improvement for everyone.

- Put everybody in the company to work in order to accomplish the transformation.

\section{Crosby Contribution}

The most useful tool developed by Crosby is his quality management maturity grid. This grid outlines corporate quality assurance and quality maturation from a level of uncertainty to one of certainty. Crosby's quality philosophy is characterized by his four absolutes (Crosby, 1984):

- Quality is defined as conformance to requirements, not goodness or elegance.

- The system for causing quality is prevention, not appraisal.

- The performance standards must be zero defects, not just "that is close enough".

- The measurement of quality is the price of nonconformance.

\section{Juran Contribution}

For Juran, he defines quality like an attitude for use, which should be managed by unified approach whose objective is to satisfy customer's needs. He suggests one procedure to handle and deal with quality. This is applicable for all functions, all echelons, and all product lines of organization. It includes three phases (Monnappa (2017):

Quality Planning: This is a process that involves creating awareness of the necessity to improve certain goals and planning ways to reach those goals. This process has its roots in the management's commitment to planned change that requires trained and qualified staff.

Quality Control: This is a process to develop the methods to test the products for their quality. Deviation from the standard will require change and improvement.

Quality Improvement: This is a process that involves the constant drive to perfection. Quality improvements need to be continuously introduced. Problems must also be diagnosed to the root causes to develop solutions. The management must analyze the processes and the systems and report back with recognition and praise when things are done right. 


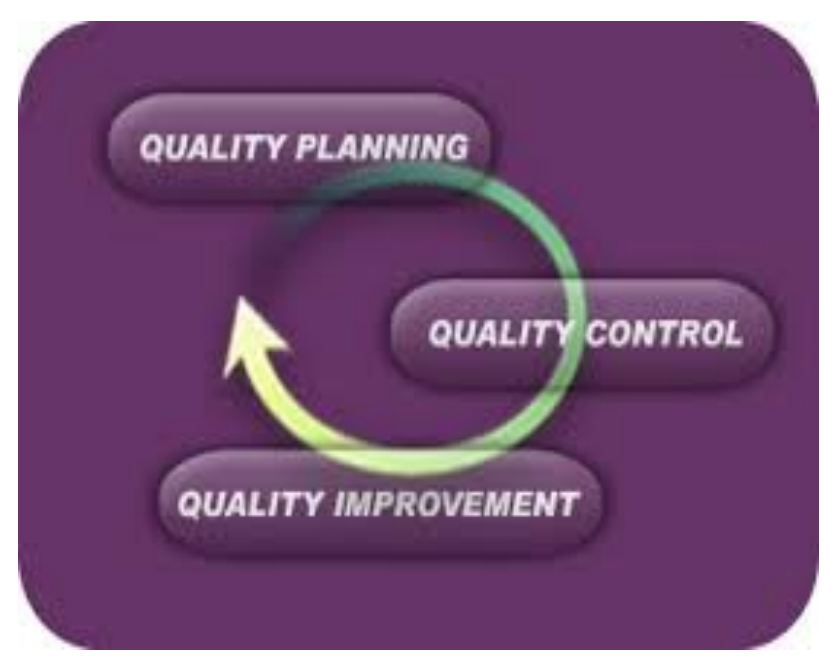

Figure 3. The Juran Trilogy

It exists with a lot of authors who contributes to the development of quality management such as Armand Feigenbaum, Kaoru Ishikawa, Genichi Taguchi, Tom peters, etc.

Furthermore, a lot of authors demonstrated that there is a direct link between quality and performance of organizations, for example: TQM is seen as a source of competitive advantage (Powel, 1995; Hackman \& Wagerman, 1995; Douglas \& Judge, 2001).

\section{Principles of Total Quality Management}

Although companies use different terms to refer to their approach to quality, they mean pretty much the same thing and embody many of the same concepts such as strategic goals, total commitment, continuous improvement, comprehensive focus, employee responsibility, job training, etc. Total quality management represents a set of management principles that focuses on quality improvement as the driving force in all functional areas and at all levels in a company. These principals include the following (Rusell $\&$ Taylor, 1997):

- The customer defines quality, and the customer's needs are the top priority.

- Top management must provide the leadership for quality.

- Quality is a strategic issue.

- Quality is the responsibility of all employees at all levels of the organization.

- All functions of the company must focus on continuous quality improvement to achieve strategic goals. 
- Quality problems are solved through cooperation among employees and management.

- Problem solving and continuous quality improvement use statistical quality control methods

- Training and education of all employees are the basis for continuous quality improvement.

- These principles are the bases of ISO 9000 certification.

\section{Interests and limits of ISO 9000 Certification}

The certification is not the only condition of success or failure of quality management. Therefore, its interests and limits will be examined.

Interests

- Certification can improve customer's confidence.

- Communicates a positive message to teamwork and clients.

- Reduces organization's cost related to quality.

- Insures continuous assessments and improvement

- Gives a positive appearance to stakeholders.

- Improves continually products and services.

- Encourages more efficient and time saving process.

- Reduces the number of external audits.

- Motivates the teamwork to achieve collective objectives.

However, there are some limits to certifications. According to Claude Jambart in his book "gestion de la qualité", he presents advantages of using quality system by comparing enterprises which adopt that system and others which do not.

Table 1. The impact of quality system on the functioning of enterprises

\begin{tabular}{|l|l|l|}
\hline & $\begin{array}{l}\text { Enterprises without } \\
\text { quality system }\end{array}$ & $\begin{array}{l}\text { Enterprises with quality } \\
\text { system }\end{array}$ \\
\hline $\begin{array}{l}\text { Process of } \\
\text { formalization }\end{array}$ & Weak, dispersed & Developed, centralized \\
\hline Documentations & $\begin{array}{l}\text { Sparse, poorly } \\
\text { controlled }\end{array}$ & Centralized, controlled \\
\hline Level of management & $\begin{array}{l}\text { Direct intervention } \\
\text { on the facts }\end{array}$ & Driving by quality system \\
\hline Culture & Oral & Writing \\
\hline $\begin{array}{l}\text { Operators } \\
\text { responsibility }\end{array}$ & De facto & Formalized \\
\hline Quality policy & Implicit & Explicit \\
\hline
\end{tabular}




\begin{tabular}{|l|l|l|}
\hline Corrective actions & dispersed & Controlled \\
\hline $\begin{array}{l}\text { Treatment of non } \\
\text { compliant products }\end{array}$ & Dispersed & Controlled \\
\hline Quality resources & Broadcast & Distinguished \\
\hline
\end{tabular}

From this table, it can be said that quality management/system (ISO9000) gives more transparency to stockholders about the enterprise.

\section{Limits of Certifications}

- Some managers do not have an adequate understanding of ISO $900 \mathrm{z}$. Thus, even if their enterprises are certified, they will spend a lot of efforts and time to lead management quality process.

- Certification can burden the functioning of a lot of functions in enterprise.

- Certification can be a very costly process for some companies, especially the small firms.

\section{The impact of quality management of Moroccan organizations}

In recent years, a lot of programs realized by Morocco are related to quality management. According to Amadour (2000), the main objectives to these programs include:

- Awareness for economic operators, particularly managers, about the role of quality.

- Training leaders of enterprises about quality management techniques.

- Certification of products and enterprises on the basis of standards.

The following are some programs that Morocco executes (Amadour, 2000):

- Constitution of associations such as AFAK, APC (Professional Associations of cement-manufacturer), FICP (Federation of Chemical Industry and Pharmaceuticals), FIMME (Federation of Engineering Industry, Metallurgical and Electric), APS (Professional Association of Sugar Bowl), and FICOPAM (Federation of Canning Industry, Fishes and Food Products)

- CGEM (General Confederation of Enterprises in Morocco or la Confédération Générale des Enterprises au Maroc)

- FCCI (Federation of chamber of commerce and industry or la Fédération des chambers de commerce et de l'industrie).

- Major groups in Morocco such as OCP (Cherifian Office for Phosphates), ONA, Wafabank, ONE, and Ciments du Maroc. 


\section{Empirical study}

The results from two studies done by other researchers are used in order to confirm or affirm the basic assumptions.

- "The quality certification and the performance of organizations: what are the convergences? Case study within the New Company AMADIR in Agadir", Lamia El Kahri, Ali Rachidi, Mostapha Amri, Université IBN ZOHR/ENCG, Agadir, Maroc (2014). It is a study done on 36 persons among Society AMADIR in Agadir Morocco.

- "Relationship between certification and export in Moroccan food industry", Yassine El Ammari, Anjoud Harmouzi, Abdelaziz Chaouch,Hassan Hadiri, Soukaina El Ammari, Université Ibn Tofail Kénitra (2015).

From the $\mathbf{1}^{\text {st }}$ empirical study, many results have been obtained:

- Usefulness of Certification: Results shows that $57 \%$ of respondents think that quality certification is very important to improve the competitiveness of the organization.

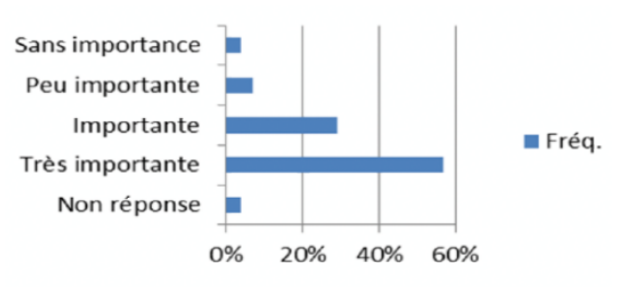

Figure 4. Usefulness of certification

- Rate of Total Sales: $68 \%$ of interviewers testify to high level of achieved sales when the organization introduces quality system in its strategy.

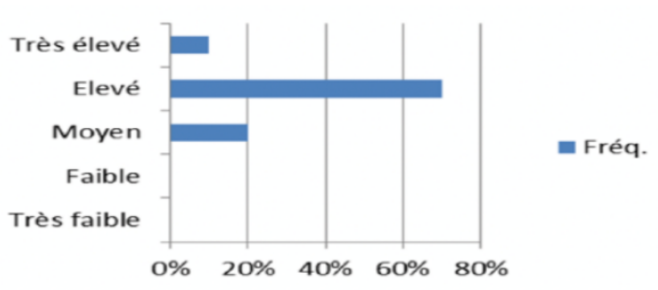

Figure 5. Rate of total sales

- Market Share: $70 \%$ of interviewers have indicated that market share progressed when the enterprise applied quality management. 


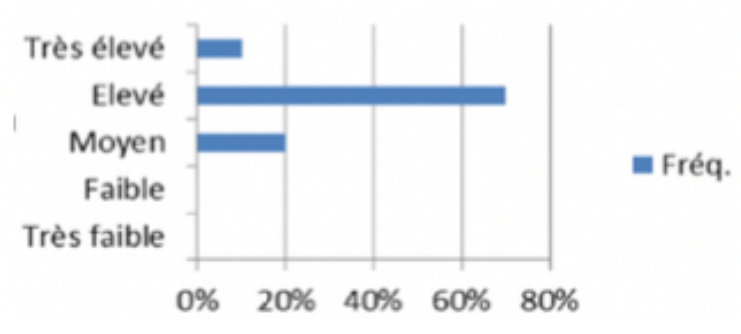

Figure 6. Market share

- The Importance of Certification to Realize Performance in Enterprise: $93 \%$ of interviewers agree certification improves the performance of the organization.

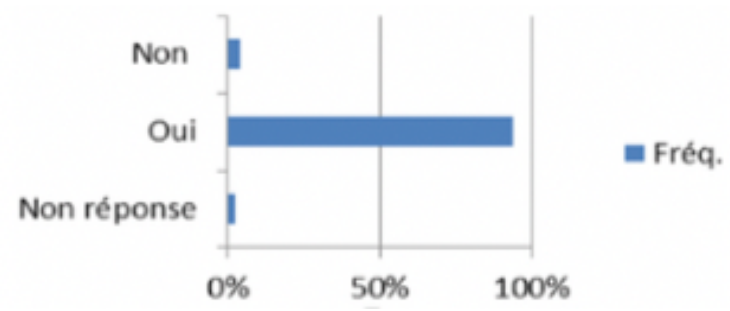

\section{Figure 7. The importance of certification to realize performance in} enterprise

From the $\mathbf{2}^{\text {nd }}$ empirical study, the result is as follows:

- Certification: $78 \%$ of companies are certified or on the way of certification as presented below:

Table 2. Distribution of companies according to certification criteria

\begin{tabular}{|l|c|c|}
\cline { 2 - 3 } \multicolumn{1}{c|}{} & Number & Percentage \\
\hline Certified companies & 58 & $62 \%$ \\
\hline On the way of certification companies & 15 & $16 \%$ \\
\hline None certified companies & 21 & $22 \%$ \\
\hline
\end{tabular}

- Distribution of Companies According to Export and Certification Criterions: $81 \%$ of companies are certified or on the way of certification. This percentage shows the importance of certification in the access to new markets, facilitation of transactions, and giving confidence to customers / consumers. 
Table 3. Distribution of companies according to export and certification criterions

\begin{tabular}{|l|c|c|c|}
\hline & Certified & In the way of certification & None certified \\
\hline \multirow{2}{*}{ Exporting companies } & 42 & 9 & 12 \\
\cline { 2 - 4 } & $67 \%$ & $14 \%$ & $19 \%$ \\
\hline \multirow{2}{*}{ None exporting companies } & 16 & 6 & 9 \\
\cline { 2 - 4 } & $52 \%$ & $19 \%$ & $29 \%$ \\
\hline
\end{tabular}

- Certification of Moroccan food companies becomes increasingly requested because of guarantee and confidence given to customers/consumers. Hence, there is the tendency of these companies to increase and diversify certifications to meet customer requirements and to maintain their competitiveness at national and international levels.

\section{Conclusion}

The results obtained from the empirical studies rely on theoretical data from authors such as Deming, Juran, and Crosby. Also, since the other parts have already been explained, it can be said that the assumptions are confirmed. Therefore, quality management can improve competitiveness and performance of Moroccan organizations.

\section{References:}

1. Avantika, M. (2017). Pioneers of project management: Deming vs. Juran vs. Crosby.

2. Arthur, G.B. (1993). Management (3rd ed). Harcourt Brace Jovanovich International Edition.

3. https://qualiblog.fr/principes-generaux-de-la-qualite/lorientationclient-dans-le-cycle-de-la-qualite/

4. http://www.businessdictionary.com/definition/competitiveness.html

5. https://www.lcl.com/guides-pratiques/zoomseconomiques/definition-competitivite.jsp

6. http://www.businessdictionary.com/definition/organization.html

7. http://www.wp1.ca/our-methods/the-deming-cycle/

8. http://asq.org/learn-about-quality/total-qualitymanagement/overview/deming-points.html

9. https://www.igi-global.com/dictionary/information-strategy/38690

10. https://www.wikipedia.org/

11. https://www.simplilearn.com/deming-vs-juran-vs-crosbycomparison-article 
12. http://docplayer.fr/23399681-The-quality-certification-and-theperformance-of-organizations-what-convergences-case-study-withinthe-new-company-amadir-in-agadir.html

13. https://www.derpharmachemica.com/pharma-chemica/food-safetyconstraints-analysis-in-moroccan-food-industry--focus-ondocumentation.pdf

14. ISO 9000: 2000. Systèmes de management de la qualité-Principes essentiels et vocabulaire

15. Jean, M. \& Florence G.G. (2007). Manager la qualité pour la première fois: conseils pratiques Diagnostic, Plan d'action, certification ISO 9000 (Deuxième tirage). Eyrolles Editions d'Organisations. Paris.

16. Moulay, A.A. (2000). La qualité : comment s'y prendre au Maroc.

17. Nguyen, N. (2006). Gestion de la Qualité. Chenelière éducation. Université de Moncton.

18. Roberta, S.R. \& Bernard, W.T. (1997). Operation Management Focusing on quality and competitiveness (2nd ed). United States of America.

19. www.tci-network.org/media/download/1185 